\title{
V4 - SAÚde PÚblica MUNDIAL EM FOCO: BIO-MANGUINHOS CRIA ESTRATÉGIAS PARA ATENDER DEMANDAS EMERGENCIAIS DA VACINA FEBRE AMARELA
}

Cintia Nunes Cardoso Lopes ${ }^{1}$, Thiago Sturiale $^{1}$, Rachelle Salem $^{1}$

${ }^{1}$ Instituto de Tecnologia em Imunobiológicos, Fundação Oswaldo Cruz, Rio de Janeiro, Brasil

\section{Objetivo}

Este trabalho descreve os esforços feitos pela área de exportação de Bio-Manguinhos pa ra mobilizar setores internos e parcerias estratégicas com o objetivo de viabilizar o atend imento de demandas emergenciais de saúde pública em países da África.

\section{Metodologia}

Em agosto de 2012, o Instituto foi contatado pelo UNICEF com o desafio de atender uma grande demanda da Costa do Marfim. Este país pretendia organizar uma campanha preventiva de vacinação contra a febre amarela no final de novembro e para tanto precisava de 6 milhões de doses da vacina.

Dada a indisponibilidade de excedente de produção, Bio-Manguinhos utilizou-se da parceria com o Programa Nacional de Imunizações que devido a não ocorrência de surto no Brasil, pôde emprestar mais de 12 milhões de doses. Por ser um produto voltado para abastecimento nacional, foi necessário readequar as embalagens com a inclusão de bulas internacionais e a mudança na disposição dos cartuchos nas caixas de embarque. Também foi necessária a emissão de certificados internacionais. Dessa forma, houve o envolvimento e comprometimento de áreas como produção, logística e qualidade. Destaca-se também a participação do INCQS, que prontamente realizou os trâmites necessários para emissão da documentação de exportação. 
Em dezembro de 2012, Bio-Manguinhos recebeu novo pedido do UNICEF para atendimento de uma epidemia de febre amarela que ocorria desde setembro no Sudão. Foram solicitadas 2,2 milhões de doses da vacina. Nesse momento, uma nova mobilização foi feita utilizando a mesma estratégia adotada no caso acima. As distribuições ocorreram após as confirmações através das ordens de compras recebidas pelo Instituto.

\section{Resultado}

De forma a atender as necessidades públicas internacionais no combate à febre amarela, Bio-Manguinhos implementou estratégias para o fornecimento da vacina estocada no mercado nacional.

A ordem de compra para a campanha da Costa do Marfim foi recebida em 31 de agosto. Foram readequados e distribuídos 17 lotes, divididos em 8 embarques, entre os dias 24 de setembro e 16 de outubro. Todos os embarques foram recebidos 5 dias após a data de saída de Bio-Manguinhos.

Para o Sudão, a ordem de compra chegou em 03 de janeiro de 2013. A exportação foi dividida em 3 embarques: nos dias 11, 15 e 18 de janeiro. Foram utilizados 9 lotes e as entregas também ocorreram dentro do prazo estimado.

\section{Conclusão}

O pronto atendimento a essas duas grandes demandas do UNICEF em 2012 ressaltou a importância de Bio-Manguinhos no cenário internacional, contribuindo com a melhoria dos padrões de saúde pública mundial. Através da mobilização de diversas áreas internas e da estratégia de parceria, foi possível o fornecimento de 8,2 milhões de doses da vacina no tempo solicitado. Os casos da Costa do Marfim e do Sudão podem ser destacados como casos de sucesso das exportações de Bio-Manguinhos. 